\title{
MORPHOLOGICAL DESCRIPTORS FOR THE CHARACTERISATION OF TEAK CLONES CUTTINGS (Tectona grandis L.F.)
}

Jorge Luis Reategui-Betancourt ${ }^{*} \odot$, Daniele Aparecida Alvarenga Arriel ${ }^{3} \odot$, Sidney Fernando Caldeia ${ }^{4} \odot$, Antonio Rioyei Higa ${ }^{5}$, Rudmilla Menezes Marques ${ }^{4} \odot$,Irivan dos Santos Gonçalves ${ }^{6} \odot$ and Diego Tyszka Martinez ${ }^{5}$ (:)

${ }^{1}$ Received on 03.07.2020 accepted for publication on 30.03.2021.

${ }^{2}$ Universidade de Brasilia, Departamento de Ciências Florestais, DF - Brasil. E-mail: <jorgereategui91@gmail.com>.

${ }^{3}$ Universidade Federal de Uberlândia, Instituto de Ciências Agrarias, Monte Carmelo, MG - Brasil. E-mail: <daniarriel@ufu.br>.

${ }^{4}$ Universidade Federal de Mato Grosso, Faculdade de Engenharia Florestal, Cuiabá, MT - Brasil. E-mail: <sidneycal@gmail.com> and $<$ rudmillamm.16@gmail.com>.

${ }^{5}$ Universidade Federal do Paraná, Departamento de Ciências Florestais, Curitiba, PR - Brasil. E-mail: <antonio.higa@gmail.com> and <diegotyszka@hotmail.com>.

${ }^{6}$ Proteca- Biotecnologia Florestal Ltda, Cuiabá, MT - Brasil. E-mail: <irivan@proteca.com.br>.

${ }^{*}$ Corresponding author.

\begin{abstract}
Teak (Tectona grandis) is a forest species cultivated in tropical regions worldwide, due to the traits of its wood and its great economic value on the market. In Brazil, original plantations are being replaced by selected clonal forests, which generate the need and interest to protect this genetic material based on the current legislation. The legal requirements for cultivar protection are that the genotype must result from genetic improvement and provide distinguishability, homogeneity, and stability (DHS). This work identifies morphological descriptors in teak cuttings to assist the clone protection process of the species. The study was conducted in a completely randomized design with the evaluation of 7 clones and 15 cuttings per clone, at 30 , 60,90 , and 120 days old. The information was also organized based on the arrays of presence and absence of variations for each clone, for 21 morphological traits. Subsequently, genetic similarity measures were estimated using the Jaccard index and the UPGMA clustering method. The clones with the 12, 7, 9, and 11 morphological traits formed the morphological descriptors for the 30,60,90, and 120 days old cuttings, respectively. The traits of the leaf blade: length, width, length/width ratio, green intensity, and the brightness of the leaf, were common for all the evaluated ages, but their respective levels of expression were different.
\end{abstract}

Keywords: Cultivar protection; Distinguishability; Similarity.

\section{DESCRITORES MORFOLÓGICOS PARA A CARACTERIZAÇÃO DE MUDAS CLONAIS DE TECA (Tectona grandis L.F.)}

RESUMO - Teca (Tectona grandis) é uma espécie florestal cultivada em regiões tropicais do mundo, devido às características de sua madeira e seu grande valor econômico no mercado. No Brasil, as plantações originais estão sendo substituídas por florestas clonais selecionadas, o que gera a necessidade e o interesse de proteger esse material genético com base na legislação vigente. Os requisitos legais para proteção de cultivares são que o genótipo seja resultante de melhoramento genético e apresentar distinguibilidade, homogeneidade e estabilidade (DHE). Este trabalho identifica descritores morfológicos em mudas de teca para auxiliar no processo de proteção dos clones da espécie. O estudo foi conduzido em delineamento inteiramente casualizado com avaliação de 7 clones e 15 mudas por clone, avaliados com 30, 60, 90 e 120 dias de idade. As informações foram organizadas com base nas matrizes de presença e ausência das variações para cada clone, por 21 características morfológicas. Posteriormente, foram estimadas medidas de similaridade genética, por meio do índice de Jaccard e o agrupamento pelo método UPGMA. Foi possivel diferenciar os clones, com 12, 7, 9 e 11 caracteres morfológicos para compor os descritores morfológicos com 30, 60, 90 e 120 dias de idade, respectivamente. As características da lâmina foliar: comprimento, largura, relação comprimento/largura, 
intensidade da cor verde da folha e brilho da folha, foram comuns para todas as idades avaliadas, mas seus respectivos niveis de expressão foram diferentes.

Palavras-Chave: Proteção de cultivares; Distingibilidade; Semelhança.

\section{INTRODUCTION}

Teak (Tectona grandis L.f.) belongs to the Lamiaceae family and it is one of the most cultivated tropical wood species in the world. The estimated area planted with species varies between 4.4 and 6.9 million hectares. There are approximately 29 million hectares of this species in natural forests (Kollert and Kleine, 2017). In Brazil, at the end of the 1960s, the first commercial teak plantations were made. In $2018,93,957$ hectares were obtained with this species in the state of Mato Grosso, followed by the state of Pará (IBA, 2019). Currently, original plantings of the species are replaced by improved and selected clones. This generated interest to apply Intellectual Property Law on these materials, based on the Cultivar Protection Law No. 9,456 of April 25 $5^{\text {th }}, 1997$, regulated by Decree No. 2,366 of November $5^{\text {th }}, 1997$.

The genotype characterization of cultivated plants contributes in breeding programs and in the process of cultivar protection (Alcântara et al., 2016; Chimello et al., 2017). The protection of a new cultivar is the result of genetic improvement and its identification should be possible through morphological traits: distinguishability, homogeneity, and stability DHS (Santos and Pacheco, 2011). Morphological characterization provides an identity for each genotype through the use of a series of descriptors that indicate genetic variability and distinguishability compared to the other genotypes. These traits, called morphological descriptors, must be heritable, controlled by few genes, and their expression should be equal in all the environments (Burle and Oliveira, 2010).

Currently, in Brazil, teak has few descriptors established by the public sector for the protection of its cultivars, although it is an economically relevant species. The descriptors' drafting may range from seeds to adult individuals found in the field. In the case of perennial species such as teak, the use of seedlings brings advantages such as the early evaluation of the genetic material, requiring less space for its establishment and fewer financial resources for evaluations.
Some studies using teak clones at different ages, allowing the differentiation among groups of genotypes and origins, also evaluating their genetic variability (Miranda, 2013; Gunaga et al., 2013; Baretta, 2016; Alcântara et al., 2016; Chimello et al., 2017). However, these studies did not define a descriptor table for teak clones. Therefore, this work identifies morphological descriptors to differentiate cuttings teak clones, which contribute to the process of clonal protection of the species by the National Plant Variety Protection Service. (Serviço Nacional de Proteção de Cultivares - SNPC).

\section{MATERIAL AND METHODS}

\subsection{Morphological descriptors}

The study was carried out in the nursery of Proteca Biotecnologia Florestal Ltda Company, located in the municipality of Várzea Grande, Mato Grosso, Brazil. Seven clones were evaluated in a completely randomized design (CRD), with 15 cuttings (repetitions) of each clone: the clones 1, 2, and 3 (from the Solomon Islands); clone 4 (from Brazil); clone 5 (from Malaysia); clone 6 (from Indonesia); and clone 7 (from Tanzania).

To produce the cuttings, the clones were first multiplied by means of micropropagation. The explant consisted of the apical meristem of selected trees in adult clonal forests, which was collected from the upper branches of the crown without cutting down the mother tree. The number of subcultures varied between the genotypes and the time of the experiment, using 15 to 30 subcultures. Then, the cuttings of all genotypes were simultaneously shown in $55 \mathrm{~cm}^{3}$ plastic tubes filled with a substrate of carbonized rice husks, pine husks, and vermiculite. Cytokinin was used as growth regulator and the cuttings were kept in a greenhouse with a mean temperature of $30{ }^{\circ} \mathrm{C}$. The irrigation was conducted by micro-sprinkling which over time, between 2 and $15 \mathrm{~mm}$, maintaining a relative humidity close to $80 \%$. Mineral fertilization with macro and micronutrients was used on the substrate and by fertigation.

Revista Árvore 2021;45:e4522 


\subsection{Data collection and analysis}

The cuttings were evaluated after 30,60, 90, and 120 days following the transplanting of the in vitro micropropagation to the nursery, from September to December. The evaluated traits are related mainly to the leaf morphology, stem, and apex cuttings. Initially, 21 traits were identified as potential morphological descriptors to differentiate the cuttings from the clones (Table 1). These traits were organized in sheets, properly arranged to facilitate the data organization and the filling. Regarding the leaf traits, the second pair of leaves from the upper part of the apex of the plant was used.

The main morphological traits are shown for the different ages clones with their respective evaluated levels of expression (Figure 1 and 2).

The evaluation of various traits in the cuttings was based on a scale of codes with sequential values ranging from $1-2$ to $1-4$. For example, "stem: color"; value 1 for "light green"; value 2 for "light brown"; and value 3 for "dark brown". Thus, for each clone was noted the code that corresponded to each of the evaluated traits. Traits were considered as potential descriptors when $100 \%$ of the plants showed homogeneity. Therefore, the analysis did not consider the percentage of atypical plants. Traits whose expressions were not homogeneous within the same clone were marked with the letter " $X$ ". In order to evaluate quantitative morphological traits: length, width, and length/width ratio of the leaf blade, the means $(\bar{x})$ was calculated for each trait by clone and two measuring ranges were established based on the overall average for each trait: (1) When the value observed was lower than the general $\bar{x}$, and (2) when the value observed was higher than the general $\bar{x}$. Likewise, the clones that showed no homogeneity for quantitative traits were marked with the letter X.

To determine the genetic similarity and cluster analysis for each age of evaluation was used only the

Table 1 - Morphological traits evaluated in teak clonal cuttings.

Tabela 1 - Características morfológicas avaliadas em mudas clonais de teca.

\begin{tabular}{|c|c|c|c|}
\hline \multirow[t]{2}{*}{$\mathrm{N}^{\circ}$ Trait } & \multicolumn{3}{|l|}{ Levels of expression in different ages } \\
\hline & 60 days & 120 days & $\mathrm{Fa}$ \\
\hline 1.Stem: color & $\begin{array}{lr}\begin{array}{l}\text { Intensity of green } \\
\text { color: light, dark }\end{array} & \text { brown, } \mathrm{C}\end{array}$ & $\begin{array}{l}\text { een, light } \\
\text { ark brown }\end{array}$ & $\overline{\mathrm{VG}}$ \\
\hline 2.Stem: Intensity of the pubescence & \multicolumn{2}{|c|}{ Low, medium, high } & VG \\
\hline 3.Stem: pubescence & \multicolumn{2}{|l|}{ Absent, present } & VG \\
\hline 4.Stem: color of pubescence & \multicolumn{2}{|l|}{ White, light brown, dark brown } & VG \\
\hline 5.Stem apex: pubescence & \multicolumn{2}{|l|}{ Absent, present } & VG \\
\hline 6.Stem apex: pubescence color & \multicolumn{2}{|l|}{ white, brown } & VG \\
\hline 7.Leaves: leaves arrangement at the apical bud & \multicolumn{2}{|l|}{ Curved, } & VG \\
\hline 8.Leaf: petiole & \multicolumn{2}{|l|}{ Absent, present } & VG \\
\hline 9.Leaf blade: format & \multicolumn{2}{|l|}{ Elliptical, obovate } & VG \\
\hline 10.Leaf blade: marginal incision & \multicolumn{2}{|l|}{ Dentate, entire } & VG \\
\hline 11.Leaf blade: prominence of main nerves & \multicolumn{2}{|l|}{ Non-salient, salient } & VG \\
\hline 12.Leaf blade: venation prominence & \multicolumn{2}{|l|}{ Non-salient, salient } & VG \\
\hline 13.Leaf blade: length $(\mathrm{cm})$ & \multicolumn{2}{|l|}{ Short, long } & VG/MI \\
\hline 14.Leaf blade: width $(\mathrm{cm})$ & \multicolumn{2}{|l|}{ Narrow, large } & VG/MI \\
\hline 15.Leaf blade: ratio length/width $(\mathrm{cm})$ & \multicolumn{2}{|l|}{ Low, high } & VG/MI \\
\hline 16.Leaf blade: pubescence on the upper face & \multicolumn{2}{|l|}{ Absent, present } & VG \\
\hline 17.Leaf blade: pubescence on the lower face & \multicolumn{2}{|l|}{ Absent, present } & VG \\
\hline 18.Leaf blade: venation & \multicolumn{2}{|l|}{$\begin{array}{l}\text { Does not touch the marginal, } \\
\text { Touches the marginal }\end{array}$} & VG \\
\hline $\begin{array}{l}\text { 19.Leaf blade: leaves pigmentation of stem } \\
\text { apex per Tectoquinone }\end{array}$ & \multicolumn{2}{|l|}{ Absent, present } & VG \\
\hline 20.Leaf blade: intensity of the leaf color green & \multicolumn{2}{|l|}{ Light, medium, dark } & VG \\
\hline 21.Leaf blade: leaf brightness & \multicolumn{2}{|l|}{ Low, high } & VG \\
\hline
\end{tabular}




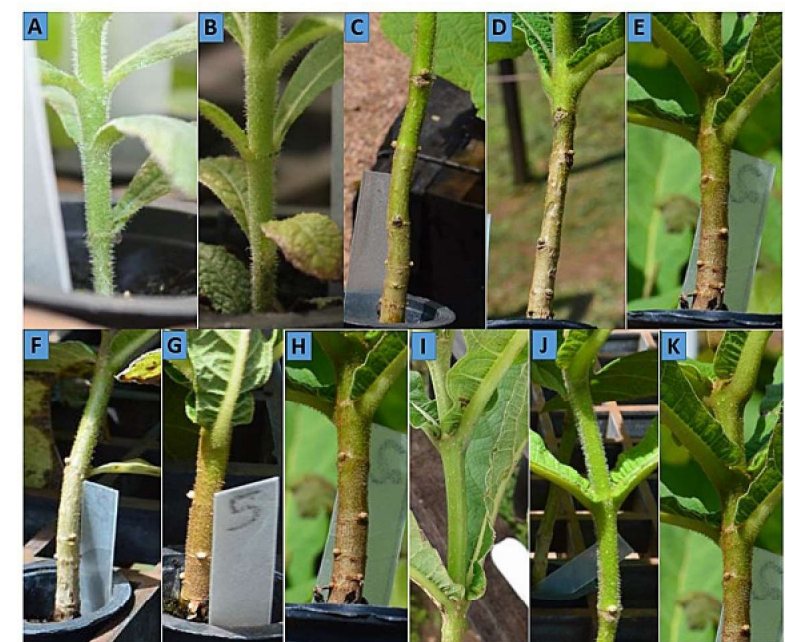

Figure 1 - Morphological traits evaluated: Stem: Intensity of light green color (A) and dark color (B); pubescence high (A) and low (B) intensity (at 30 and 60 days old clones). Stem: light green color (C), light brown color (D), and dark brown color $(\mathrm{E})$; pubescence white color (F), light brown color $(\mathrm{G})$, and dark brown color $(\mathrm{H})$. Stem apex: pubescence absent (I) and present $(\mathrm{J}, \mathrm{K})$; pubescence white color $(\mathrm{J})$ and brown color $(\mathrm{K})$ (at 90 and 120 days old clones).

Figura 1 - Características morfológicas avaliadas: Caule: Intensidade de cor verde claro $(A)$ e cor escura $(B)$; pubescência alta (A) e baixa (B) intensidade (clones com 30 e 60 dias de idade). Caule: cor verde claro (C), marrom claro $(D)$ e marrom escuro (E); pubescência cor branca $(F)$, marrom claro $(G)$ e marrom escuro (H). Apice do caule: pubescência ausente (I) e presente $(J, K)$; pubescência coloração branca $(J)$ e coloração marrom (K) (clones com 90 e 120 dias de idade).

morphological traits that showed homogeneity within individuals and distinguishability among the clones. The binary matrices of the presence (1) and absence (0) were arranged according to the level of expression of the traits presented by each clone at each age. After obtaining the binary matrix, the genetic similarity among the evaluated clones at each age were calculated using the Jaccard similarity index (SJ).

$S J=\frac{c}{a+b-c}$

where:

$\mathrm{a}=$ number of morphological traits occurring in clone 1 ;

$\mathrm{b}=$ number of morphological traits occurring in clone 2;

$\mathrm{c}=$ number of common morphological traits in the two clones.

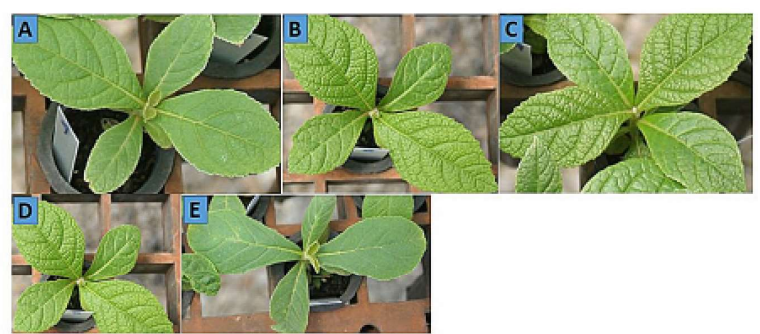

Figure 2 - Morphological traits evaluated in the leaf blade: Intensity of the green leaf color, light (A), medium (B), and dark (C) (at 30 and 60 days old clones); Shape elliptical (D) and obovate (E); margin incision dentate (D) and entire (E); venation prominence, salient (D) and non-salient (E) (at 30 days old clones).

Figura 2 - Características morfológicas avaliadas na lâmina foliar: Intensidade da coloração verde da folha, clara (A), média (B) e escura (C) (clones com 30 e 60 dias de idade); Forma elíptica (D) e obovada (E); incisão de margem dentada (D) e inteira (E); proeminência da venação, saliente (D) e não saliente (E) (clones com 30 dias de idade).

Then, the clustering analysis was performed (clustering of arithmetic average among unweighted pairs) with the UPGMA method using the Past 3.x program (Hammer et al., 2001). Then, the cutoff point was determined on the dendrogram to obtain a better determination of the number of conformed groups.

\section{RESULTS}

\subsection{Morphological descriptors for clonal cuttings at 30 days}

For cuttings at 30 days of age, 12 distinctive traits were observed among the seven clones that remained homogeneous in all the individuals. These traits were the following: stem, color and intensity of the pubescence; for the leaf blade, the shape, incision in the margin, prominence of main nerves, venation prominence, length, width, length/width ratio, pigmentation of the stem apex leaves per Tectoquinone, the intensity of the leaf green color, and leaf brightness.

The stem color intensity was light green in clones 1,6 , and 7 , with the others presenting a dark green color. The stem pubescence intensity was low for clones 3 and 4, medium for clones 1, 2, 6, and 7, and high for clone 5 . Only clone 2 presented an obovate leaf blade shape and incision at the entire margin. The others exhibited an elliptical leaf, blade shape and incisions on the dented margin. The prominence of the

\section{Revista Árvore 2021;45:e4522}


main nerves and the venation prominence were not salient in the leaf blades in clones $2,3,6$, and 7 . The presence of pigmentation at the apex of stem leaves per Tectoquinone was detected in clones $1,3,5$, and 6 . The intensity of the leaf's green color was light for clones 1, 5, and 7, medium for clones 2 and 3, and dark for clones 4 and 6 . The brightness was high for clone 4 and low for the others.

For the quantitative traits, clones 1, 2, and 3 exhibited a short length and narrow width of the leaf blade. The others presented a long length and large width. The length/width ratio of the leaf blade was high for clones 2 and 5, and low for the other clones.

The dendrogram (Figure 3A) shows the formation of three groups at a similarity of 0.36 : group one (clones 4 and 5), group two (clones 6, 7, and 1), and group 3 (clones 2 and 3). Clones 6 and 7 share the greatest number of characteristics and they have a similarity of 0.6 ; these differ only by the characteristics of the leaf blade: the length/width ratio, pigmentation of stem apex leaves per Tectoquinone, and the intensity of the leaf's green color.

\subsection{Morphological descriptors for clonal at 60 days}

For the cuttings at 60 days old, seven traits were observed in the differentiation clones: for the stem, intensity of the green color and intensity of pubescence; for the leaf blade, length, width, length/ width ratio, intensity of leaf green color, and the leaf brightness.

Regarding stem color, only clone 5 presented a dark green color and the others exhibited a light green tone. The stem pubescence intensity was low in clones 1,2 , and 4, and the others presented a high intensity. For the intensity of the green color in the leaves, clones 2 and 3 presented a light green color, clones 1 and 7 exhibited a medium green color, and clones 4, 5 , and 6 presented a dark green color. Regarding leaf brightness, clone 4 presented high brightness, being different from the other clones, which showed low brightness.

Regarding quantitative traits, the leaf blade length was short for clones 2 and 3, and long for the other clones. The leaf blade width was narrow for clones 2, 3, and 6, and large for the other clones. The length/width ratio of the leaf blade was low for clones 2,4 , and 5, and high for the other clones. Three groups were formed in the cluster analysis at a similarity of 0.39 (Figure 3B): group one (clones 5 and 4), group two (clones 6, 7, and 1), and group 3 (clones 2 and 3 ). Clones 1 and 7 showed a similarity of 0.75 and differed only by the intensity of the stem pubescence.

\subsection{Morphological descriptors for clonal cuttings at 90 days}

After 90 days, nine traits were observed in the plants that allowed the differentiation clones: for the stem, color and pubescence color; for the stem apex, pubescence and pubescence color; for the leaf blade, length, width, length/width ratio, intensity of leaf green color, and brightness.

With respect to stem color, clones 1 and 2 were light green; clones 4, 5, 6, and 7 had a light brown color; and clone 3 was dark brown. Regarding stem pubescence color, clones 1,2 , and 4 had a white color, clone 7 was a light brown color, and clone 3 was a dark brown color. At this age, two more traits allowed the distinction clones: the presence of pubescence in the apical part of the stem (with only clone 2 having no pubescence) and the color of the apical part (with only white color in clone 1 while the others clones were brown color).

In regard to the intensity of the green color of the leaves, clone 4 had a medium green color, clone 5 a dark green color, and the others clones had a light green color. Also, only clone 4 exhibited intense brightness while the others clones exhibited low brightness.

Among the quantitative traits, clones 3, 5, and 6 presented a short leaf length and the other clones a long leaf length. Regarding leaf width, clones 3, 5 , and 6 presented a narrow width, while the other clones presented a large width. Concerning the width/ length ratio, clones 1, 2, 4, and 7 had lower ratios and the others a high ratio.

The clustering analysis resulted with similarity of 0.37 in two groups separated (Figure 3C): group one (clones 4, 7, 2, and 1) and group two (clones 3, 5, and 6). Amid these groups, clones 5 and 6 were very similar (similarity of 0.8 ), differing only by the characteristic intensity of the green color of the leaf blade. Clones 1 and 2 had a similarity of 0.63 differing by the traits of the stem apex (pubescence and pubescence color).

\section{Revista Árvore 2021;45:e4522}




\subsection{Morphological descriptors for clonal cuttings at 120 days}

After 120 days, eleven morphological traits were observed in the clonal cuttings: for the stem, the color, pubescence, and pubescence color; for the stem apex, pubescence, and pubescence color; for the leaf blade, length, width, length/width ratio, venation, intensity of leaf green color, and brightness.

For the qualitative traits such as stem color, clone 1 was a light green color, clones 2,4 , and 5 were a light brown color, and the others clones were dark brown color. Stem pubescence was absent in clones 5, 6, and 7 , and the stem pubescence color of clones 1 and 4 were a light brown color, and clones 2 and 3 were brown color. The pubescence of the stem apex was absent in clone 2, clone 1 exhibited white pubescence while the others clones were brown pubescence. Regarding leaf blade venation, clones 2 and 4 were the only ones that did not touch the margin. For the intensity of the leaf color, clones 1, 2, and 6 were light green color while the other clones were dark green color. Further, clone 4 was the only one that exhibited high brightness.
A

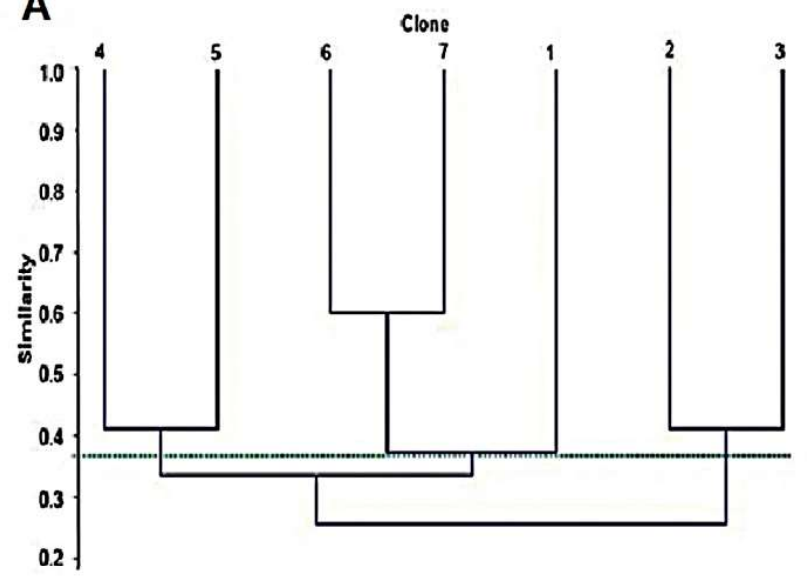

C

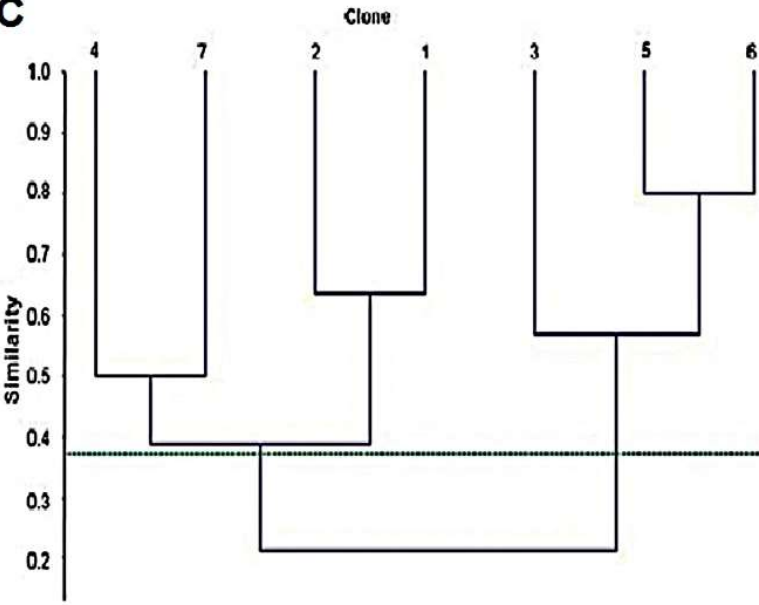

B

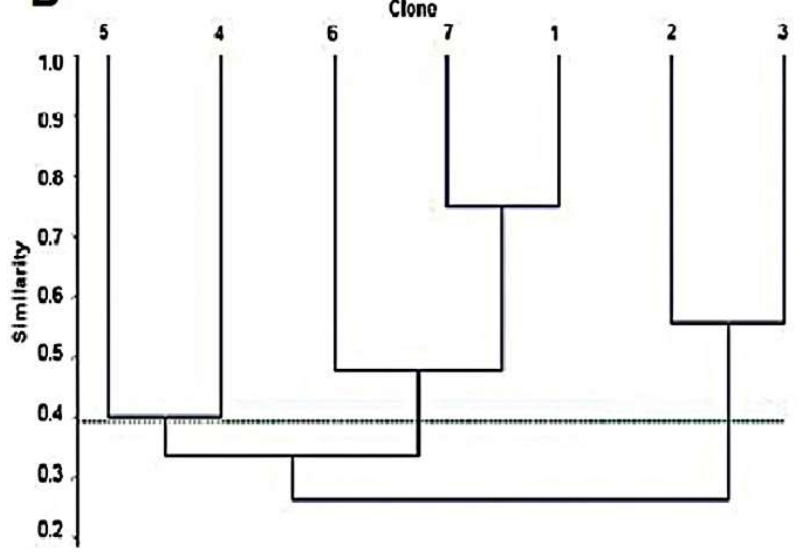

D

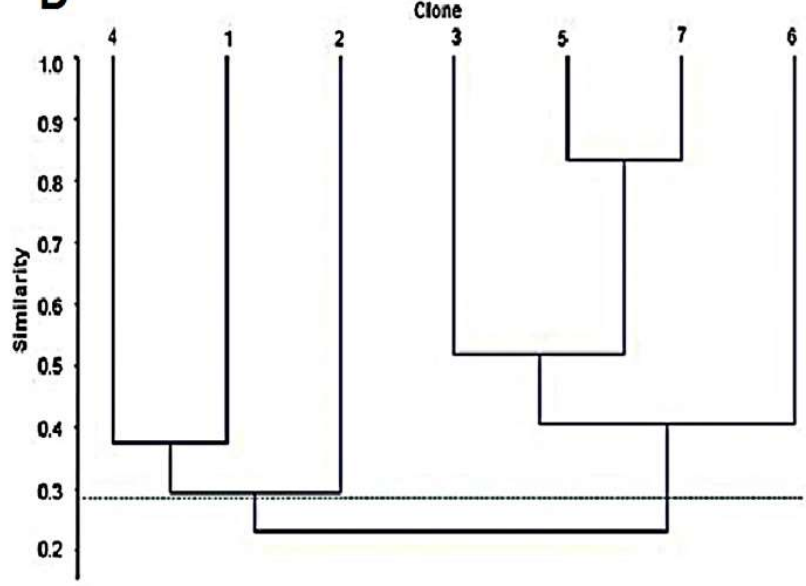

Figure 3 - Similarity dendrogram of seven clones of Tectona grandis at 30 (A), 60 (B), 90 (C) and 120 (D) days old, by the UPGMA clustering method based on the Jaccard similarity index, analyzed at Várzea Grande, MT. Similarity was obtained through the evaluation of 12, 7, 9 and 11 morphological traits respectively for each age.

Figura 3 -Dendrograma de similaridade de sete clones de Tectona grandis com 30 (A), 60 (B), 90 (C) e 120 (D) dias de idade, pelo método de agrupamento UPGMA baseado no índice de similaridade de Jaccard, analisado em Várzea Grande, MT. A similaridade foi obtida através da avaliação de 12, 7, 9 e 11 característica morfológicas respetivamente para cada idade.

Revista Árvore 2021;45:e4522 
With respect to the quantitative traits of the leaf blade, clones 2, 3, 5, and 7 presented a short length and the others clones a long one. Concerning the width of the leaf blade, clones 3, 5, and 7 were narrower and the others were wide. Regarding the length/width ratio, only clones 3 and 6 presented a high ratio. Based on the clusters, a similarity of 0.38 was observed at two groups (Figure 3D): group one (clones 4, 1, and 2) and group two (clones 3, 5, 7, and 6). Clones 5 and 7 presented the highest similarity, with a distance of 0.83 , differing only by their stem color.

Overall, 12, 7, 9, and 11 traits were identified in clonal cuttings at $30,60,90$, and 120 days of age, respectively, with their codes (Table 2). These traits enabled the differentiation clones being highly homogeneous, and they can be used as morphological descriptors. Traits that did not allow the differentiation clones and/or they did not show homogeneity were discarded in the list of morphological descriptors.

Among all the evaluated traits, only the leaf blade brightness presented the same pattern in all the genotypes after 30, 60, 90, and 120 days. Regarding stem apex, the traits pubescence and pubescence color remained the same also after 90 and 120 days. The remaining traits exhibited variation along the evaluations.

\section{DISCUSSION}

The elaboration of descriptors for the teak production is a recurring demand from producers and it's necessary investments in research, especially, to improving the management of species stands. Furthermore, the descriptors provide information

Table 2-Morphological descriptor codes that allow the distinction between seven clones of Tectona grandis L.f. at different ages, analyzed at Várzea Grande, MT.

Tabela 2 - Códigos dos descritores morfológicos que permitem a distinção entre sete clones de Tectona grandis L.f. em diferentes idades, analisadas em Várzea Grande, MT.

\begin{tabular}{lcccc}
\hline & \multicolumn{4}{c}{ Age and clone code } \\
\cline { 2 - 5 } & 30 days & 60 days & 90 days & 120 days \\
\hline 1 & 121122111211 & 1122221 & 112222111 & 12222221211 \\
2 & 222211112121 & 111111 & 111122111 & 22311121111 \\
3 & 211111111221 & 1211211 & 332311211 & 32323112221 \\
4 & 211122221132 & 1122132 & 212322122 & 22223221122 \\
5 & 231122222211 & 2222131 & 222311231 & 21123111221 \\
6 & 121111222231 & 1221231 & 222311211 & 31123222211 \\
7 & 121111221111 & 1222221 & 222322111 & 31123111221 \\
\hline \multicolumn{3}{l}{ Source: The authors. } \\
Fonte: os autores.
\end{tabular}

Fource: The authors. and knowledge to infer the genetic variability from different genotypes and to support programs for species improvement. The results show the identification of descriptors that distinguish genotypes at different ages and it was studied in this research. The cuttings at 30 and 120 days of age stood out, because they showed the highest number of traits (12 and 11, respectively) for the differentiation clones. Previous studies on the subject failed to assess the diversity from cuttings of different genotypes, nor a descriptive table (Chimello et al., 2017).

The analysis about the diversity of clones showed their distinction, with clones of high similarity and specific traits, presented in the dendrograms. For black wattle (Acacia mearnsii De Wild.) the morphological traits for seed and clonal tests showed a dissimilarity higher than 55\% (Flôres Junior, 2015). Therefore, it is possible that the variability of teak exhibits a narrow genetic base and limits the number of descriptors.

Clones at 30 and 60 days of age were clustered into three groups, with genotypes similarities according to their age proximity. After 90 and 120 days, only two groups were formed with clone 7 and it was grouped differently from its age group. After 30 days, the separation of the genotypes was clearer due to their lower similarity with plants of other ages. From one age to another, these variations in groups were influenced by the development conditions of the cuttings. This was reflected in their traits.

Among the evaluated traits, only leaf blade brightness remained with the same pattern in genotypes after 30, 60, 90, and 120 days. At the stem apex, the pubescence and pubescence color traits were valid for plants after 90 and 120 days. The level of expression of the remaining traits varied along the evaluations. This variation in the expression of the different traits at each age is the result of the genetics of each clone, and of physiological and environmental factors over time (Encinas et al., 2005). Therefore, identical genotypes with the same environmental conditions, they have identical morphological traits.

The genotypes with greater similarity were grouped together regardless of their origin (Solomon Islands, Brazil-Cáceres, Indonesia, Malaysia, and Tanzania). Some clones may share similarities that are not associated precisely to their places of origin (Fofana et al., 2009; Chimello et al., 2017). Also,

Revista Árvore 2021;45:e4522 
the similarity of the morphological traits between some genotypes can result from more closely related populations (Da Costa et al., 2014), while others may be similar or divergent in genotypes with the same or different origins (Alcântara and Veasey, 2013; Alcântara et al., 2016).

In breeding programs, genotypes with similar morphological traits experience fewer benefits that result from the combination and genetic gain (Chimello et al., 2017; Prasetyo et al., 2020) when compared to phenotypically divergent genotypes (Alcântara and Veasey, 2013; Chimello et al., 2017; Flôres Junior et al., 2018). Therefore, in potential future breeding programs, it is important to consider the dissimilarity of genotypes to obtain higher genetic gains per generation (Chawhaan et al., 2003; Vasudeva et al., 2004; Chaudhari et al., 2018; Huang et al., 2019).

For other forest species in Brazil such as eucalyptus (Eucalyptus spp.), Pinus (Pinus spp.), and Australian red cedar (Toona ciliata M. Roemer var. australis), the traits related to the mature plants are also used related to the cuttings in the protection process (MAPA, 2019). Flôres Junior et al. (2018) found morphological descriptors for adult individuals and seeds in black wattle. Nevertheless, the characterization of seedling or cuttings is easy for all the forest species. In addition, the procedure is advantageous for the costs and the time required to obtain information.

Comparing some morphological leaf traits in teak after 120 days of transplantation in the nursery, Chimello et al. (2017) observed that the leaf blade shapes were elliptical and obovate. On the other hand, this research proved at 30 days, only one clone showed the obovate leaf shape and entire margin, compared from other clones of elliptical leaf shapes and a dented margin. At 60, 90, and 120 days, the same trait of leaf blade shape could not be used to distinguish the clones, presenting an elliptical shape. However, the mature leaves were close to falling, they presented a leaf shape between an elliptical and obovate one. This variation in leaf shape was also found by Miranda (2013) when distinguished between an elliptical shape in younger leaves and an oval shape in larger and more mature leaves.

Some leaf traits did not allow the differentiation of the genotypes, nor pubescence on the upper and lower surface of the leaf blade. Chimello et al. (2017) stated that teak presents serous hairs, with hypoid intense glandular ones on the abaxial surface, and glandular pilosities and hispidus on the adaxial face. Clones at all ages exhibited a petiole but the young leaves of the apex was not considered because they did not present this structure. Teak is considered a particular species, because the presence of a petiole is variable during the plant development, with mature petiolate plants becoming sessile at younger stages (Lyngdoh et al., 2007). Also Chimello et al. (2017) observed that the variable that most differentiated the genotypes is the leaf apex shape (cuspidate, retuse, and obtuse). Furthermore, the authors recommended using features such as: stem diameter, fresh and dry weight of aerial parts, fresh and dry mass of the roots as relevant characteristics for understanding the spatial variability found in this species. Finally, to have robust descriptors must be carried out other tests, considering different environments, locations, time of year, management of cuttings in the nursery, etc.

\section{CONCLUSION}

The morphological descriptors $(12,7,9$ and 11) were established to differentiate clones of $T$. grandis at $30,60,90$, and 120 days of age cuttings, respectively. The morphological traits that distinguished the seven clones: 1) the leaf blade (format, marginal incision, prominence of main nerves, and venation prominence) at 30 days old; 2) the stem intensity of the pubescence at 30 and 60 days old clones; 3) stems color of pubescence; 4) the stem apex pubescence and pubescence color, at 90 and 120 days old clones; 5) the stem pubescence at 120 days old clones; 6) the stem color; and 7) the leaf blade (length, width, ratio length/width, intensity of the leaf green color, leaf brightness) for clones of all ages. This is considered for the level of expression was different for each. In this way, traits for clonal cuttings can be used to form the table of descriptors in the process of cultivar protection for the species.

\section{AUTHOR CONTRIBUTIONS}

Jorge L. Reategui-Betancourt, Diego Tyszka Martinez and Daniele Aparecida A. Arriel: data collection, analyze and text written. Diego Tyszka Martinez, Daniele Aparecida A. Arriel, Sidney Fernando Caldeira and Antonio Rioyei Higa:

Revista Árvore 2021;45:e4522 
methodological contributions, supervisão de pesquisa emrevisão de texto. Jorge L. Reategui-Betancourt, Rudmilla Menezes Marques and Irivan dos Santos Gonçalves: data collection and experimental set-up. Diego Tyszka Martinez, Daniele Aparecida A. Arriel and Sidney Fernando Caldeira: project management.

\section{REFERENCES}

Alcântara BK, Veasey EA. Genetic diversity of teak (Tectona grandis L.F.) from different provenances using microsatellite markers. Revista Árvore. 2013; 37(4):747-758. doi: https://doi.org/10.1590/S010067622013000400018

Alcântara BK, Ortega EMM, Souza VC. Identification of morphological descriptors for characterization of teak (Tectona grandis L. f.). Advances in Forestry Science. 2016; 3(1): 1-5. doi: 10.34062/afs.v3i1.2930

Baretta MC. Crescimento e caracterização morfológica de clones de teca no sudoeste de Mato Grosso [dissertação]. Universidade Federal Mato Grosso, Cuiabá; 2016.

Burle ML, Oliviera M. Manual de Curadores de Germoplasma-Vegetal: Caracterização Morfológica. Embrapa Recursos Genéticos e BiotecnologiaDocumentos (INFOTECA-E); 2010. [cited 2020 june 28]. Available at https://www.iba.org/publicações

http://www.infoteca.cnptia.embrapa.br/infoteca/ handle/doc/913190

Chawhaan PH, Khobragade ND, Mandal AK. Genetic analysis of fruit and seed parameters in teak (Tectona grandis L. F.): Implications in seed production programme. The Indian Journal of Genetics and Plant Breeding. 2003; 63(3): 239-242. ISSN 0975-6906.

Chaudhari C, Kumar R, Dhaka RK, Parekh V, Sankanur MS, Prajapat P et al. Genetic diversity analysis of teak in South Gujarat by RAPD marker. International Journal of Chemical Studies. 2018; 6(6): $260-267$

Chimello AM, Jesus JG, Teodoro PE, Rossi AAB, Araújo KL, Marostega TN, et al. Morphological descriptors and ISSR molecular markers in the evaluation of genetic variability of Tectona grandis genotypes. Genetics and molecular research. 2017; 16(2): 1-6. doi: http://dx.doi.org/10.4238/ gmr16029665

Da Costa JO, Cremasco JPG, Matias RGP, Da Silva DFP, Salazar AH, Bruckner CH. Divergência genética entre populações de pessegueiro baseada em características da planta e do fruto. Ciência Rural, Santa Maria. 2014; 44(10): 1770-1775. doi: https:// doi.org/10.1590/0103-8478cr20131010

Encinas IJ, Silva GF, Pinto JRR. Idade e crescimento das árvores. Idade e crescimento das árvores; Brasília, (Comunicação Técnica Florestal da UnB,7); 2005.

Flôres Junior PC. Caracterização morfológica e análise de divergência genética entre clones de acácia-negra (Acacia mearnsii De Wild.) [Dissertation]. Universidade Federal do Paraná, Curitiba; 2015.

Flôres Junior PC, Ikeda AC, Schuhli GS, Silva LD, Higa AR. Repeatability and genetic dissimilarity using biometric characteristics of black wattle seeds Advances in Forestry Science. 2018; 5(2): 333-337.

Fofana IJ, Ofori D, Poitel M, Verhaegen D. Diversity and genetic structure of teak (Tectona grandis L. f.) in its natural range using DNA microsatellite markers. New Forests. 2009; 37(2): 175-195. doi: 10.1007/s11056-008-9116-5

Gunaga RP, Surendran T, Prabhu HN. Morphological variation and delineation of teak (Tectona grandis L.f.) clones of Kerala through leaf character: implication for seed orchard management. Mysore Journal of Agricultural Sciences. 2013; 47(1): 202205.

Hammer Ø, Harper DAT, Ryan PD. Paleontological statistics software package for education and data analysis. Palaeontologia Electronica. 2001; 4(1): 1-9.

Huang G, Liang K. Zhou Z, Yang G, Muralidharan EM. Variation in Photosynthetic Traits and Correlation with Growth in Teak (Tectona grandis Linn.) Clones. Forests. 2019; 10(1): 1-11. doi: https://doi.org/10.3390/f10010044

Indústria Brasileira de Árvores - IBÁ. Relatório anual 2019 [cited 2020 june 25]. Edition 24. Available at https://www.iba.org/publicações 
Kollert W, Kleine M. The global teak study analysis, evaluation and future potential of teak resources. IUFRO World Series Volume 36, Vienna; 2017. ISSN 1016-3263.

Lyngdoh N, Gugana RP, Vaduseva R. Delineation of teak (Tectona grandis L. f.) clones through leaf descriptors. Indian Journal of Forestry. 2007; 30: 21-28.

Ministério da Agricultura Pecuária e Abastecimento - MAPA. Proteção de cultivar-florestais. [cited 2019 apr. 23]. http://www.agricultura.gov.br/assuntos/ insumos-agropecuarios/insumos-agricolas/protecaode-cultivar/florestais

Miranda MC (2013) Caracterização morfológica e avaliação do desenvolvimento inicial de clones de teca (Tectona grandis L.f.) [dissertação].
Universidade Federal de Mato Grosso, Cuiabá; 2013.

Prasetyo E, Indrioko S, Na'iem M, Matsui T, Matsuo A, Suyama Y, Tsumura Y, et al. Genetic diversity and the origin of commercial plantation of Indonesian teak on Java Island. Tree Genetics \& Genomes. 2020; 16(2); 1-14 doi: https://doi.org/10.1007/ s11295-020-1427-5

Santos FS, Pacheco LGA. Testes de DHE. In: Ministério da Agricultura, Pecuária e Abastecimento. Secretaria de Desenvolvimento Agropecuário e Cooperativismo. Proteção de Cultivares no Brasil. Brasília, DF: MAPA/ACS; 2011.

Vasudeva R, Hanumantha M, Gunaga RP, Genetic variation for floral traits among teak (Tectona grandis Linn. f.) clones: Implications to seed orchard fertility. Current Science. 2004; 87(3): 358-362. doi: https://www.jstor.org/stable/24108942 